\title{
Changing life in the towns of north Kildare
}

\author{
Shelagh B. Waddington \\ Department of Geography, National University of Ireland, Maynooth
}

\begin{abstract}
This paper examines the growth and changes in population characteristics and lifestyle in three towns in north Kildare which have come increasingly within the influence of the Dublin Metropolitan area. The data used are primarily obtained from three surveys carried out in the towns during recent years and contrasts are made with previous work in the area. It is suggested that community life still exists in these towns but that the effects of proximity to Dublin are having ever greater impact on that life.
\end{abstract}

Key index words: urban expansion, metropolitan influence, community.

\section{Introduction}

There has been a long history of studies focussing on the growth of major urban centres and their effects on smaller communities both within the cities themselves and in the surrounding areas. As noted by Frankenberg (1966: 155), "all communities are societies, but not all societies are communities...community implies having something in common". Some authors have suggested that urban growth has led to the loss of local communities (e.g. Wirth, 1938), with workplace or interest group associations replacing those based on the local home place. Others such as Fischer (1981), have argued that, while there are some changes, local communities based on the homogeneous nature of the residents persist in many places. A third group have asserted that communities remain but they are not necessarily as limited geographically in the past, these they term 'communities liberated'.

This group (e.g. Wellman and Berkovitz, 1988) suggest that these liberated communities are still in existence but that they are not as fixed within limited territories, with members still having local linkages but also other links to the wider metropolitan area. They also suggest that more local ties may be stimulated by outside influences, particularly threats to the community from authorities or those who live outside the area and who are socially different. As noted by Davies and Herbert (1993), the sources of 'localism' may be related to the revival of grassroots community organisations and it has been suggested that this may also lead to the development of a higher level of democratic organisation in the community.

\section{The Irish context}

Early in the twentieth century it was recognised both that the outward expansion of Dublin was virtually inevitable and also that this would have a major impact on surrounding areas. As a way to ensure that this development was undertaken in a structured manner proposals were made on a number of occasions for a unitary planning authority, for example in 1926, it was proposed that the coastal area from Malahide to Killiney should be placed under the control of the city authorities (Dublin Commission, 1926). Later, various plans were produced advocating that growth should be focussed in satellite towns, within the metropolitan region, but physically separated from the current built-up area (Abercrombie $e t$

Irish Geography, Volume 33(1), 2000, 74-89. 
al., 1941, Wright, 1967). Wright identified two zones of metropolitan influence, an inner one in which Dublin was a dominant influence (including all of county Dublin plus small parts of Kildare, Meath and Wicklow) and an outer zone of weaker influence, which included much of the rest of these counties. The criteria by which the degree of influence was judged included the degree of access available to the city, the frequency of shopping visits, employment in the city and focus for shopping. Two of the towns in the present study (Maynooth and Celbridge) were included within the inner zone of influence, while the third (Kilcock) was within the outer zone. Wright (1967: 33) also considered that, in addition to the development of satellite towns, a "policy encouraging rebuilding and of limited, compact expansion should be applied to [inland] towns" (including Maynooth and Celbridge). He envisaged an increase of 50 percent in the populations of these towns in the twenty years following the report. Wright considered that it was important that growth of housing should be paralleled by growth of employment and services in the settlements to avoid serious traffic problems caused by commuting which he considered would be by private rather than by public transport.

The Wright report was never implemented in any detail but the "push to the periphery received the imprimatur of Miles Wright" (Horner, 1992). Since the planning framework which would have ensured that this movement was undertaken in a controlled manner was not put in place, development tended to be attached to the fringes of existing settlements, where services were readily available. Despite Wright's (1967) statement that "at present [North Kildare] is not seriously threatened by urban development" (13.50), as early as 1972 Aalen noted that -

"...increases will occur because there is no firm regional control on the westward expansion of Dublin.....Although north-east Kildare is designated an area of special development control in the county plan, it will be difficult for the county council to resist development pressures, in the absence of a regional or national directive" (p.27).

In 1985 the Eastern Regional Development Organisation (ERDO) produced a plan for the development of the Dublin region up to 2011 (ERDO, 1985) which envisaged considerable population growth in the region, caused by both in-migration and by natural increase. It recommended that this growth should continue the spread from the inner city towards the suburbs and beyond into counties Kildare, Meath and Wicklow. Despite revised (lower) population estimates in the 1988 up-date of the ERDO plan (ERDO, 1988), the towns of north-east Kildare were still expected to experience an increase in population. It was envisaged that this growth would be facilitated by their proximity to National roads and rail lines. The potential and actual expansion of settlement along main roads had already been noted by Aalen in 1972, when he stated that "metropolitan spread is occurring ....by the conversion of traditional settlements along major highways into suburbs" (p. 16). In 1988 Horner charted the gradual increase in commuting possibilities by public transport over the preceding 30 years, noting that in 1986 commuting by public transport was possible within $45-50 \mathrm{~km}$ from Dublin and from the main towns up to $80 \mathrm{~km}$ distant. This increase had been facilitated by, amongst other changes, the opening of commuter rail services (including on the line serving Maynooth). Since then, road improvements have also taken place on a large scale, such as the M50 and West Link bridge, the M4 and improvements to many of the National roads connecting Dublin city to the surrounding area, further increasing the possibilities for commuting to work in Dublin. 
The potential growth identified by these reports has become reality in many of the areas on the periphery of Dublin and three towns (Maynooth, Celbridge and Kilcock) have all increased in size during the recent past. The changes resulting from this growth and the effects on lives of the residents of the towns are now examined.

\section{Data collection methodology}

The principal data sources for this study were questionnaire surveys of the residents of the towns on Maynooth, Celbridge and Kilcock in 1995, 1997 and 1998 respectively. The questions were formulated to provide both general information about the towns and also information on topical local issues. The latter was developed in co-operation with local community groups. This meant that, while most questions were common to all of the questionnaires, some were asked in only one or two localities. A two-stage sampling technique was employed. First the built-up area in each town was divided into a series of zones, each containing approximately the same number of houses. A systematic sample was then taken of households within each zone, except in the case of Kilkock where, because of its small size, all households were surveyed.

In the surveys of Maynooth and Celbridge the surveyors were able to gain responses from more than 75 percent of the target total. In Kilcock the questionnaire was completed by more than 50 percent of all households in the town. To assess the likelihood that those answering the questionnaire were representative of the residents, comparisons were made with the figures for age distribution in the most recent census of population (1991 for Maynooth and 1996 for Celbridge and Kilcock). In each of the towns the figures were comparable. The largest discrepancy was in the 65 years and older age group in Kilcock which was somewhat under-represented, possibly reflecting a greater reluctance of older people to open the door after dark. Students in Maynooth were screened out of this analysis. The majority saw themselves as only temporary residents and thus had limited engagement with the towns. The surveys of retail and service provision were undertaken in 1999.

The main data source for comparative purposes was the work undertaken by Aalen et al. in 1970 when they produced County Kildare: A geographical background for planning, which provided a comprehensive study of the physical, social and economic background of the county and made recommendations for its future development. In Volume II of the report were provided detailed studies of the towns of Kildare and these have been used in the present paper to provide comparisons with the recent surveys.

\section{Overall Population Change}

In the 1970 report it was predicted that by 1981 all three towns would have shown a considerable increase from their 1966 populations of 1254 (Maynooth), 1514 (Celbridge) and 815 (Kilcock). The reasons advanced for this growth (apart from natural increase) were:

(a) the possibility of large scale residential development in Celbridge (proposals for the building of up to 1400 houses were then under active consideration);

(b) outline planning permission had been granted for 120 private houses in Maynooth and plans existed for 30 local authority houses. A further reason identified for growth was the planned expansion of St Patrick's College - an increase from 600 to 2000 students was anticipated; 
(c) in Kilcock, residential development was predicted to be of importance from the late 1970s onward, although 30 new local authority houses and some private sites were being developed at the time of the report.

Each town experienced a level of growth towards the upper end of the predicted range (Table 1). Between 1961 and 1981 Maynooth grew by 248 percent, Celbridge 210 percent and Kilcock 104 percent. Growth has been maintained since then and is predicted to continue at least until 2006, the latest date for which Kildare County Council has made predictions (KCC, 1996).

Table 1: Population change in the three towns.

\begin{tabular}{|c|c|c|c|}
\hline & Maynooth & Celbridge & Kilcock \\
\hline Actual $1961^{2}$ & $1153^{*}$ & 1371 & 739 \\
\hline Actual $1966^{2}$ & 1254 & 1514 & 815 \\
\hline Predicted $1971^{1}$ & $2500-3500$ & $1700-1900$ & $900-1050$ \\
\hline Actual $1971^{2}$ & 1961 & 1744 & 1185 \\
\hline Predicted $1981^{1}$ & $3500-5000$ & $2000-5000$ & $1200-1600$ \\
\hline Actual $1981^{2}$ & 4015 & 4253 & 1508 \\
\hline Actual $1991^{2}$ & 6807 & 8763 & 1950 \\
\hline Actual $1996^{2}$ & 8512 & 11143 & 2238 \\
\hline Predicted $2006^{3}$ & 11,500 & 14,500 & 3500 \\
\hline
\end{tabular}

${ }^{1}$ Aalen (1970), ${ }^{2}$ CSO Census of population 1961, 1971, 1981, 1991, 1996, ${ }^{3}$ KCC, 1998.

* Estimate - subtraction of approximately 600 students from total population.

As may be seen in Figure 1, the percentage growth rate was largest in Maynooth during the period 1961-1971, but after that time Celbridge grew at the fastest rate, making it reasonable to suggest that proximity to Dublin was an influential factor in this growth, as predicted in 1970 .

The recent surveys provided further evidence for this as less than ten percent of those surveyed in Maynooth and fifteen percent in Celbridge reported that they had always lived in the town. The level of in-migration was rather lower in Kilcock, with 31.7 percent recording long-term residence there. Kilcock is $30 \mathrm{~km}$ from Dublin while Maynooth $(24 \mathrm{~km})$ and Celbridge $(20 \mathrm{~km})$ are closer. Certainly in 1970, this lower in-migration rate was predicted as Kilkock was outside the zone of development of Dublin and was "unlikely to experience 'mushroom' growth at this stage" (Aalen et al., 1970 :73). Horner (1988) also made this distinction, noting a relationship between population growth in the Dublin region and the improvement of public transport within the region facilitating commuting. The phasing of the in-migration also appears related to distance from Dublin, with Celbridge experiencing the 


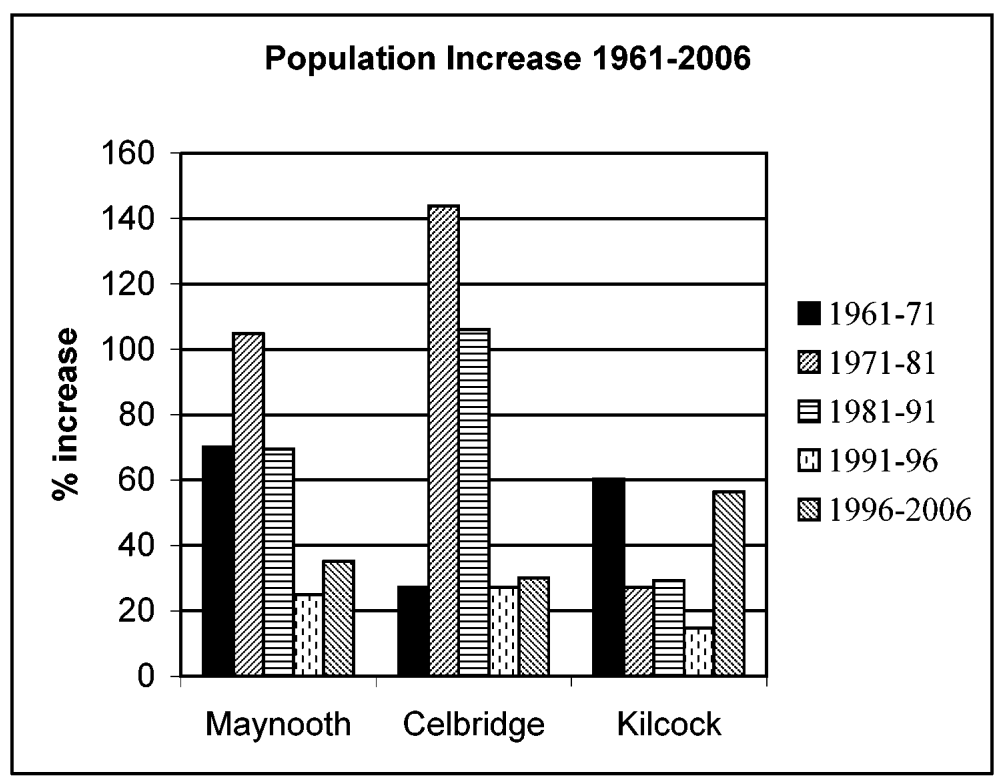

Figure 1: Population increase 1961-2006.

earliest evidence of major movements to the town, as the largest proportion of the surveyed population had moved to the town between six and fifteen years before the survey, while in Maynooth the peak was between one and five years. There was also a fairly large number who had been resident less than one year in November 1995. The largest group in Kilcock was the long term residents, most of whom were not in-migrants but those who had always lived in the town (Figure 2).

Another facet of recent population change is a reversal of the male-female ratio. In 1966 there was an excess of males over females in Kildare, even in the urban areas. This latter occurance was unusual in Ireland where urban areas usually had an excess of females over males, explicable in terms of the opportunities for female employment in service industries. In Celbridge the ratio was as low as 845 females per 1000 males compared with 878 per 1000 in Kilcock and 938 women per thousand men in Maynooth. By 1996, there had been a dramatic turn around with more females than males in all three towns. The structure was less imbalanced than was the case in 1966. Celbridge still had the lowest proportion of females (1005:1000) and Maynooth the highest (1038: 1000), with the ratio in Kilcock being 1024:1000. The increase in employment in service industries both within the towns and within the Greater Dublin area would presumably be influential in this change. Evidence for changing employment is shown both by the results of the 1996 census and by the surveys of both Celbridge and Maynooth (see section on employment below).

Between 1966 and 1996 the age structure of the towns became younger with an increase in the relative proportion of the population in the 15-44 years age group and a decrease in the 45-64 age group in all three north Kildare towns (Figure 3). This is undoubtedly due to the greater employment opportunities in the district and in Greater Dublin which has both kept this age-group within the towns and encouraged in-migration. Kilcock, the town furthest from Dublin recorded the smallest increase in the proportion of its population in the 15-44 age group, providing support for the suggestion that distance from Dublin influenced migration 


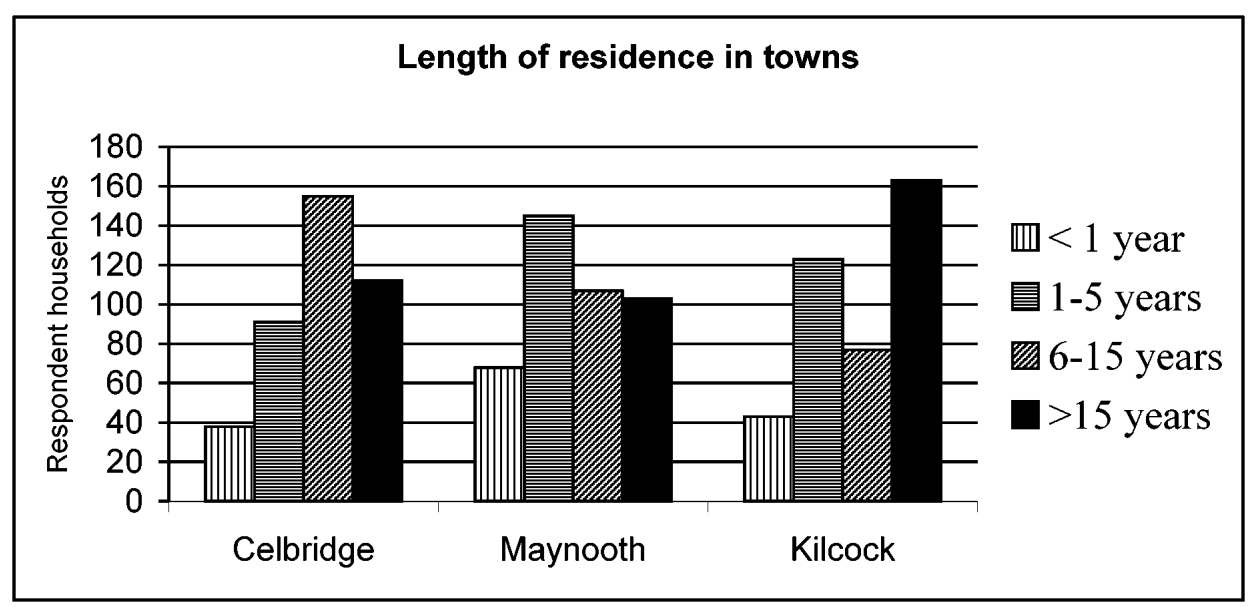

Figure 2: Length of residence in the three towns.

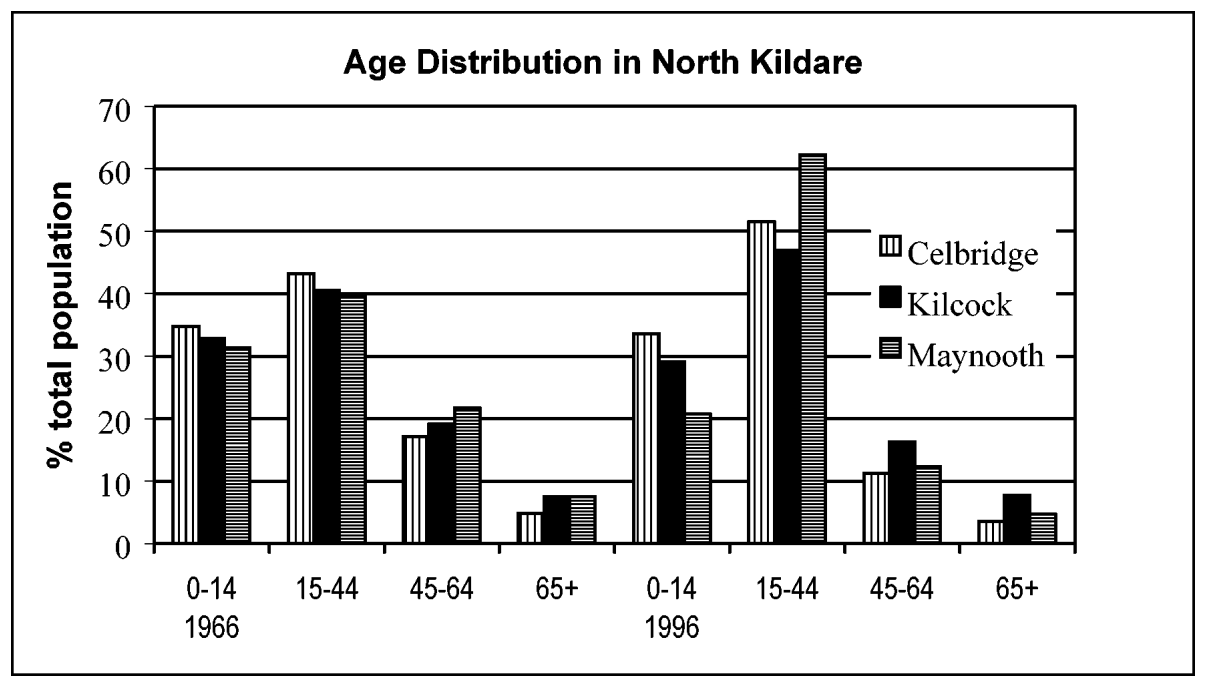

Figure 3: Age structure in the three towns 1966 and 1996.

patterns. It had the lowest level of in-migration and was the only one of the three towns to show an increase in the proportion of the population over 65 years, growing slightly from 7.48 to 7.73 percent. It must be noted that the very high proportion in the $15-44$ years age group in Maynooth is influenced by the number of students resident in the town, but even when this group is removed from the total population, it is still higher than in the other two towns.

\section{Attitudes to change}

Attitudes towards further growth of the three towns were not explored in the 1970 study, but questions were asked about this in two of those undertaken more recently in Maynooth and in Kilcock. At the time of the Maynooth study the Kildare Draft Development plan 
(KCC, 1995) had recently been made available for inspection by the public. It was proposed that there should be 280 acres (c. 113 ha) of land rezoned for housing development. If all of this land was developed for housing this could lead to an population of over 21,000 by 2006. When the Kilcock study was undertaken, the final version of the Development Plan was on display (KCC, 1999), which recommended a growth from the 1996 population of approximately 2300 to 3500 by 2006 .

In Maynooth, only 30.3 percent were in favour of unrestricted growth and 44.2 percent were opposed to this, while 17 percent felt that amenity development should keep pace with any future growth. In Kilcock, however, 59 percent of respondents considered that the proposed increase in population was acceptable and only 26.5 percent rejected the idea. A reason for this difference may be that the growth of Kilcock over the previous period had been less rapid than that of Maynooth and the former town had relatively few facilities/amenities. There would perhaps be a perception that increased population would be advantageous in negotiation with the authorities for improvements and also would encourage commercial firms, such as supermarkets to locate in the town. In Maynooth, growth had been much greater and a proportion of residents stated that they felt amenities must be developed in parrallel with housing. It may be suggested that those who were against any further growth may also have felt that there was currently pressure on the facilities available in the town. Some previous studies of communities facing considerable growth have identified a relationship between length of residence and attitude to growth, with long term residents being more likely to support growth than those who had moved more recently to the area (e.g. Connell, 1974), but no evidence was found in the present surveys. Indeed, in the case of Maynooth, the residents who had lived in the town for the shortest time were the most likely to favour further development.

\section{Employment}

\section{Local employment}

In all three towns at least 70 percent of people within the economically active group were employed locally in the 1960s (Aalen et al., 1970, Table 2). Even in the 1960s, the majority of those who worked outside their home town travelled to or towards Dublin. The proportion who travelled to Dublin was greatest in Celbridge (the town closest to Dublin), with eighteen percent doing this, in comparison with Maynooth (seven to thirteen percent) and Kilcock (fourteen percent). In the latter town it was noted that a further eleven percent travelled eastwards to Lucan, Leixlip and Maynooth. No detailed surveys were carried out in the other two towns, but it would be reasonable to suppose that this Dublin-directed movement was replicated.

By the 1990s, the proportion working locally had declined steeply, with only nineteen percent of those surveyed in Maynooth , fifteen percent in Celbridge and 17.6 percent in Kilcock working in their respective towns. This partly reflects some changes in employment opportunities (for example, the closure of a bakery in Kilcock and textile factories in Celbridge) but also an increasing focus on Dublin as 41 percent of respondents in Maynooth and 61.2 percent in Celbridge worked somewhere in county Dublin, while 28 percent of those in Kilcock (144 people) worked in the inner city of Dublin. 


\section{Female employment}

The proportion of women in the labour force has increased in all three towns since 1968. At that time, Celbridge had the highest participation rate (33 percent),with Maynooth having 30.2 percent and Kilcock only 23.5 percent. The 1970 report suggested that participation rose with proximity to Dublin, a conclusion supported by these figures. By 1996, Maynooth now had the highest proportion of female members of the labour force (41.5 percent compared with 40.0 percent in Celbridge). The proportion of women in paid employment showed the largest percentage increase in Kilcock - rising to 37.9 percent, but was still lower than the other two towns, suggesting that the distance effect from Dublin was still influential.

Table 2: Location of employment in towns in north Kildare (percent).

\begin{tabular}{llccccc}
\hline & \multicolumn{2}{c}{$1968^{1}$} & \multicolumn{4}{c}{$1990 \mathrm{~s}^{2}$} \\
& Local & Dublin & Local & $\begin{array}{c}\text { Central } \\
\text { Dublin }\end{array}$ & $\begin{array}{c}\text { Other } \\
\text { Dublin }\end{array}$ & $\begin{array}{c}\text { All } \\
\text { Dublin }\end{array}$ \\
\hline Maynooth & $74-78$ & $7-13$ & 19.0 & 16.0 & 25.0 & 41.0 \\
Celbridge & 70 & 18 & 15.0 & 21.8 & 39.4 & 61.2 \\
Kilcock & 70 & 14 & 17.6 & 28.0 & N/A & N/A \\
& & & & & & \\
\hline
\end{tabular}

Sources: 1 Aalen, 1970b,

2 Waddington, 1996 (Maynooth), 1998 (Celbridge) and 1999a (Kilcock).

\section{Types of employment}

The types of employment showed some changes during the period. Noteworthy was the decline in importance of manufacturing in all of the towns. This was particularly marked in Celbridge which had the largest amount of workers in this group (38 percent in 1966 and 19 percent in 1996). In this town and surrounding area there were a number of manufacturing industries in 1966 which had closed by 1996, including textiles and meat processing, while the newer industries, for example electronics, did not employ large numbers of local residents. Maynooth experienced a decrease from 18.4 to 17.7 percent in industrial workers, reflecting the relatively low level of employment available locally in this category at any time - there was only one fairly large industrial employer in Maynooth during the period - an animal feed mill. In all three towns there has been an increase in those involved in the professional sector, with an increase of 10 percentage points in both Celbridge and Maynooth. In Maynooth by 1996 this had become the largest employment sector, employing 25.4 percent of the workforce, while it was second most important in Celbridge and third most important in Kilcock. Maynooth's relatively high percentage in 1966 (15 percent) was almost certainly related to the presence of the National Seminary and Pontifical University. Of particular interest was the increase in proportion of female workers in this group, rising from 40.7 percent to 61.6 percent in Maynooth and from 37.0 to 66.6 percent in Celbridge but by only 6.2 percent to 66.2 percent in Kilcock. These increases reflect both the overall increase in female participation in the work force and also the growth of jobs in this sector over the time period in the Greater Dublin area in general. The apparently anomalous finding in Kilcock is related partly to the very small number of persons involved in 1966 - with only 30 people in total in this sector of whom 18 were female. Many of these women were religious sisters as 
there was a convent in the town. The total number in 1996 was much larger for both male and female workers in this sector.

\section{Transport to work}

While levels of commuting to Dublin have clearly increased in all three towns since 1968, there have been important changes in both the provision and usage of public transport for work purposes. Each town in 1968 had at least two bus services which enabled people to reach work in central Dublin before 09.00 (Table 3), and none had a rail service. Despite this, Aalen et al. (1970:73) suggested that up to 60 percent of city centre commuters from Kilcock travelled by public transport. No detailed surveys of transport use were carried out in the other two towns, but it would be reasonable to suppose that figures were comparable. Somewhat earlier studies elsewhere also noted this availability and usage of public transport as being an important factor for the development of commuter settlements, for example Johnson (1956) and Connell (1974) around Belfast and London respectively. In 1988 Horner suggested that the gradual extension of the commuting hinterland of Dublin was particularly related to improvements in public transport, including the opening in 1981 of the suburban rail passenger services in Maynooth. The station in Celbridge did not open for such services until 1994 and that in Kilcock shortly before the date of the survey in 1998. Both Horner (1988) and Duffy (1987) noted that the impact of private transport availability was also an important factor influencing the growth of commuting from the wider surroundings of the city.

Table 3: Number of public transport connections reaching central Dublin before 09.00.

\begin{tabular}{lrrrr}
\hline & \multicolumn{2}{c}{$* 1966$} & \multicolumn{2}{c}{$* * 1990$ s } \\
& Bus & Rail & Bus & Rail \\
\hline Maynooth & 4 & 0 & 7 & 3 \\
Celbridge & 2 & 0 & 6 & 3 \\
Kilcock & 2 & 0 & 1 & 1 \\
\hline
\end{tabular}

Sources: *Aalen et al. (1970)

**Dublin Bus, Bus Éireann and Iarnród Éireann timetables (1996-98).

In the 1990s the possibilities of reaching city centre destinations before 09.00 by public transport had increased in both Maynooth and Celbridge, while Kilcock had lost one bus service but had gained a train service. Bus commuting from Kilcock was reduced shortly after the questionnaire survey was completed when some services were withdrawn by Bus Éireann. Despite the improvement in rail services in all three settlements and of buses in Celbridge and Maynooth, usage of public transport for work purposes decreased in the period between the two studies, to fourteen percent in Maynooth, sixteen percent in Celbridge and 20.6 percent in Kilcock. In both Kilcock and Celbridge the convenience of private transport was the most important influence on this decision - selected by more than 30 percent in both towns. In all cases timing and frequency of services were also seen as important deterrents to the use of public transport. The location of the station for Celbridge, approximately $2 \mathrm{~km}$ from the town, and the Dublin terminus at Heuston station $(2.5 \mathrm{~km}$ from the city centre), without onward suburban rail connections would be likely to influence the perception of limited convenience of public transport. In the Kilcock survey, those not using public transport (particularly the railway) were asked to state whether they would consider using it if services were improved. 
Almost 75 percent stated that this was at least possible, but 56 percent indicated that this would only be the case if a regular hourly service to Dublin was provided during the whole day - providing further support for the finding that flexibility of travel time was a major influence in usage of private rather than public transport.

\section{Life in the towns of north Kildare}

\section{Reasons for choosing to live in north Kildare}

In each of the three 1990s surveys, respondents were asked to identify at least one reason why they chose to live in their town. In all three towns access to other places for purposes of work or study was the most selected reason why they had moved to their new town (Table 4). An earlier study of villages in Ireland (Gillmor, 1988) found this to be the second most selected reason for moving to the new location (28.8 percent) after availability of housing (38.3 percent of responses). Connell (1974) also identified accessibility to work as being very important in people moving to a commuter settlement near to London. In both of these earlier studies a large proportion of the respondents had to travel outside of their village to obtain this work, particularly those who lived in settlements in the vicinity of larger centres. For both Maynooth and Celbridge residents the venue was largely Dublin, whereas in Kilcock many respondents identified places within 8 kilometres or actually in the town. This may illustrate the effect of distance from Dublin on the level of influence of the opportunities for employment there. In all of the recent studies cost of accommodation was the next most selected reason after access, which would appear to correspond broadly to the most important reason in the Gillmor study. Interestingly, only in Maynooth was the attractiveness of the property considered to be important by nearly as many people as price. In the 1974 study the attractiveness of the surrounding area was considered to be an important factor, and this was also the case in Kilcock, where twelve percent regarded this as being the most important factor. In comparison, only 5.6 percent of Celbridge respondents identified this factor as being the most important one - possibly reflecting the larger size of the town. Those residents were generally amongst those who had lived longest in the town, suggesting a decrease in importance of this factor as the town had increased in size. Price of accommodation was considered to be most important by more recent residents when compared with those who had been living in the north Kildare towns for longer periods, reflecting the recent increases in house prices in the Greater Dublin area.

\section{Most attractive features of life in north Kildare}

In addition to identifying why they had chosen to move to north Kildare, the respondents in Maynooth and Celbridge were also asked to identify the most attractive and least attractive features of life in their towns. While there were obviously some variations in specific attractions, e.g. the River Liffey in Celbridge or St Patrick's College in Maynooth, there was considerable agreement on general type of features (Table 5). In both towns more than twelve percent of respondents considered aspects of the community or local people were attractions to their town, supporting the view that these towns did retain a sense of community despite their growth in recent times. The attractions of the country/ rural aspects of life were also considerable, particularly in Celbridge (23.9 percent of respondents) and to a lesser degree in Maynooth (12.6 percent). A smaller group of Maynooth respondents did identify the small size of the town as being attractive. All of these would suggest that the towns were seen as still rural communities by their residents. However, it must be noted that more than twelve 
percent also considered access to Dublin as being the most attractive feature of life in their town, suggesting that a sense of community was not particularly strong for these people.

Table 4: Most important reasons for choosing to live in the towns (percent respondents).

\begin{tabular}{lccr}
\hline & Maynooth & Celbridge & Kilcock \\
\hline & 36.4 & 28.9 & 5.8 \\
Access to Dublin & 19.4 & 12.1 & 14.1 \\
Access elsewhere & 14.2 & 23.3 & 16.9 \\
Cost of accommodation & 12.9 & 12.5 & 8.3 \\
Attraction of property & 3.4 & 8.2 & 4.1 \\
Appearance of town & 3.6 & 3.6 & 3.3 \\
Amenities & 2.3 & & \\
Access to home & & 2.2 & 12.0 \\
Local industry & & 5.6 & 21.9 \\
Village/rural life & 7.8 & 3.5 \\
Multiple reasons & 387 & 305 & 242 \\
Other & & & \\
Number of respondents & & & \\
\hline
\end{tabular}

\section{Least attractive features of life in north Kildare}

Factors associated with traffic and road works were seen in both towns as major detractions to life. At the time of the Celbridge survey traffic congestion in the main street of the town was regarded by inhabitants (and other interested parties) as a major problem. Since the Community Council was anxious to test public opinion about possible solutions, this was an important focus of the survey. This was likely to have had some influence on the proportion of respondents who would regard traffic as the least attractive feature of their town, so that the finding that this was the least attractive feature of life for 52.2 percent of respondents may be somewhat exaggerated. In Maynooth only 10.1 percent regarded traffic as a major detraction to life in the town, but a further 24.7 percent regarded road works, inadequate footpaths or poor repair of roads as detractions. At the time of the survey the construction of the Leixlip-Kilcock section of the M4 was nearing completion and the associated link roads were being built, bringing considerable disruption to the town (Table 6). Only in Celbridge did a sizeable number of respondents ( 8.7 percent) consider the growth of the town to be a detraction to life and in neither town did many people report that the community or groups of people within the community to be an unattractive feature of life. The higher percentage in Maynooth (4.4 percent compared to 1.1 percent in Celbridge) related mostly to some hostility to students expressed by other residents.

\section{Facilities/Amenities in the towns}

One obvious change between the 1960s and the studies of the 1990s was the large increase in numbers of both retail and service establishments provided locally. This growth obviously reflects the increase in population of all of the settlements and also the increasing variety of types of retail outlet and professional services required by people. For example, 
garden centres, video hire shops, beauty salons and leisure/fitness clubs were not present anywhere in 1968 (Table 7). However the importance of local shops has declined markedly. For example in 1970, Kilcock was stated to be the largest service centre in North Kildare and it had more shops than Celbridge, Maynooth or Leixlip. It served a large hinterland and provided a large range of basic goods and services for its inhabitants and those of the surrounding area. Less than six percent of the residents surveyed shopped for food outside of Kilcock (although many households did make a shopping trip to Dublin at least once every three to four weeks).

Table 5: Most attractive features of life in north Kildare towns.

\begin{tabular}{lcc}
\hline Attractive feature & \multicolumn{2}{c}{ Percent responses } \\
& Maynooth & Celbridge \\
\hline Community/ people & 12.4 & 14.0 \\
Country/rural & 12.6 & 23.9 \\
Quietness & 9.9 & 6.5 \\
College & 17.0 & \\
Access to Dublin & 13.1 & 12.5 \\
Pubs/ nightlife & 6.4 & 1.3 \\
Small size & 5.4 & \\
Royal canal & 2.7 & 16.5 \\
Historic features & & 4.2 \\
River Liffey & & 4.0 \\
Nothing/no idea & 5.2 & 17.1 \\
Other & 15.3 & 449 \\
Number of respondents & 400 & \\
\hline
\end{tabular}

Table 6: Least attractive features of life in north Kildare.

\begin{tabular}{lcc}
\hline Unattractive feature & \multicolumn{2}{c}{ Percent responses } \\
& Maynooth & Celbridge \\
\hline Traffic & 10.1 & 52.2 \\
Litter/dirt & 11.6 & 7.8 \\
Size/ growth of town & & 8.7 \\
Community/ people & 4.0 & 1.1 \\
Lack amenities/ facilities & 17.4 & 2.5 \\
Drink/ drugs/pubs & 4.4 & 3.6 \\
Road works/ roads/ footpaths & 24.7 & \\
Specific area of town & 13.1 & 2.5 \\
No opinion & 3.8 & 21.6 \\
Other & 10.9 & 386 \\
Number of respondents & 391 & \\
\hline
\end{tabular}

By 1998 only approximately 20 percent of residents of Kilcock shopped locally for their major food purchases, probably a reflection on the fact that this was the only one of the survey 
towns which did not have a major supermarket. There were a large number of purchases still made in the town but these were commonly convenience goods or petrol. In contrast 61.4 percent of Celbridge respondents and 79.8 percent of Maynooth residents did their food shopping in their own town. Questions about other purchases were not asked in Kilcock, but in the Maynooth and Celbridge the degree of focus on Dublin city centre was considerable, for example more than 75 percent of clothes purchases and over 60 percent of electrical goods were purchased there. Despite the presence relatively close to the three towns of out of town shopping centres, central Dublin retained its massive dominance, with less than ten percent of purchase of any type made in these centres.

Table 7: Retail establishments in the towns.

\begin{tabular}{|c|c|c|c|c|c|}
\hline \multirow[t]{2}{*}{1968} & \multicolumn{4}{|c|}{ Percent establishments in each category } & \multirow[b]{2}{*}{ Total } \\
\hline & Food & Household & Other non-food & Services & \\
\hline Maynooth & 46.5 & 17.9 & 7.1 & 28.6 & 28 \\
\hline Celbridge & 51.5 & 19.3 & 9.7 & 19.3 & 31 \\
\hline Kilcock & 43.7 & 20.5 & 7.7 & 28.3 & 39 \\
\hline
\end{tabular}

Source: Aalen et al. (1970).

\begin{tabular}{lccccc}
\hline Present & Food & $\begin{array}{c}\text { Percent establishments in each category } \\
\text { Household }\end{array}$ & Other non-food & Services & Total \\
\hline Maynooth & 15.5 & 20.0 & 21.8 & 42.7 & 110 \\
Celbridge & 10.9 & 25.2 & 20.2 & 43.7 & 119 \\
Kilcock & 27.1 & 20.3 & 11.9 & 40.7 & 59 \\
\hline
\end{tabular}

Source: Survey, 1999.

Professional service provision has also increased greatly in the three towns during the period between the 1968 survey and the present (Table 8) particularly reflecting the increase of population. In both Celbridge and Maynooth a large majority of the children received their second level education in their home town. In 1968 this would not have been possible due to lack of provision of suitable establishments. While Maynooth had a post-primary section attached to the boys' national school (and a junior vocational school was under construction - to provide classes up to age 15) there was no post-Intermediate Certificate education provided and there was no boys' second level school in Celbridge. No questions were asked about the use of the other professional services but it must be presumed that sufficient of the local population use them to ensure their financial viability as it would be unlikely that many people would travel large distances to use many of them. Maynooth was, and still remains, the location of the only third level provision in the three towns.

\section{Amenity provision}

In 1968, no questions were asked about what amenities people resident in north Kildare felt they required, although there were certainly relatively few facilities available according to the report, which mentions only community halls in Maynooth and Kilcock and a small branch library in Maynooth. There were also GAA clubs in all three towns and another sports 
club was located between Maynooth and Kilcock. Maynooth was identified as being one of four sites for a swimming pool within county Kildare. It was noted that "construction of this pool has not yet commenced". This remains true in the 1990s though demand is very strong in all three towns, with 48 percent of Kilcock residents, 44 percent Celbridge and 44 percent of those of Maynooth suggesting that this amenity was required in their town. In both Kilcock and Maynooth the provision of a gym or sports centre was regarded as desirable by more than 25 percent of respondents. Only thirteen percent of respondents in Celbridge felt that this was required. Facilities of this type were available in the town, suggesting that these were inadequate, too expensive or not known to respondents. In 1970, the only leisure activity for which an out-of-town venue other than Dublin city centre was suggested was the cinema. At that time the nearest cinema to the three towns was located in Lucan. This has subsequently closed, but facilities were available in the 1990s both in the city centre and at the nearest out-of-town shopping centres of Blanchardstown, Liffey Valley and Tallaght. This was reflected in the relatively low percentages of respondents who felt that a cinema in their town was desirable - seven percent in Maynooth, less than five percent in Celbridge and two percent in Kilcock.

Table 8: Provision of Professional Services.

\begin{tabular}{|c|c|c|c|c|c|c|}
\hline & \multicolumn{3}{|c|}{1968} & \multicolumn{3}{|c|}{1999} \\
\hline & Maynooth & Celbridge & Kilcock & Maynooth & Celbridge & Kilcock \\
\hline Second level boys & & & $*$ & & $*$ & \\
\hline Second level girls & & $*$ & & & $*$ & \\
\hline Second level mixed & $*$ & & & $*$ & & $*$ \\
\hline Public library & & & & $*$ & $*$ & $*$ \\
\hline Solicitor & $*$ & & & $*$ & * & * \\
\hline Auctioneer & $*$ & & & $*$ & $*$ & $*$ \\
\hline Accountant & & & & $*$ & $*$ & $*$ \\
\hline Architect & & & & $*$ & $*$ & \\
\hline Hotel & & & & $*$ & $*$ & \\
\hline Doctor & $*$ & $*$ & $*$ & $*$ & $*$ & $*$ \\
\hline Dentist & & $*$ & $*$ & $*$ & $*$ & $*$ \\
\hline Optician & & & & $*$ & $*$ & $*$ \\
\hline Chiropodist & & & & $*$ & $*$ & \\
\hline Chiropractor & & & & $*$ & & \\
\hline Physiotherapist & & & & $*$ & $*$ & \\
\hline
\end{tabular}

The variety of leisure facilities has grown in the three towns, particularly in Maynooth and Celbridge, to include golf and pitch and putt facilities, tennis clubs, soccer clubs, and a variety of other clubs and societies. In Celbridge, the Community Council own premises in which various gym and fitness activities are held. This provision is reflected in the level of focus on the towns for these activities, for example 39 percent of Maynooth respondents who carried out any type of sporting activity did so in their town and a further fifteen percent within 5 miles $(8 \mathrm{Km})$ of the town. However, the Dublin focus was maintained for the rest as 20 percent went to Dublin, although it must be noted that 25 percent went elsewhere. In Celbridge more detailed questions were asked dealing with particular sports, of which almost 
all were carried out by the majority of their participants in the town. Those for which people travelled outside the town were particularly swimming, golf, hockey and fishing. Only for the playing of hockey did more than 20 percent of respondents travel to Dublin. The only other leisure activity for which information was collected was a visit to a public house. In all three towns more than 70 percent who visited a public house did so in their town of residence, while in Maynooth 10.3 percent and in Celbridge 6.7 percent went to Dublin. No information was collected about this in the earlier study, and so it is impossible to make comparisons but it is likely that relatively few people other than those who worked in Dublin would have gone regularly to drink there in the past, although decreased tolerance of drinking and driving would tend to inhibit people from moving out of their place of residence more in the $1990 \mathrm{~s}$ than in the past.

\section{Conclusions}

There have been considerable changes in the towns of north Kildare since the late 1960s, some related to their increase in size and others to the changing lifestyles of those who are resident in them. They show increasing dependence on Dublin for employment and increasing reliance on private transport, but there are greater amenities and services within all of the towns, suggesting that they are providing more for their residents than just becoming a "huge hotel without a roof" (Frankenberg, 1966). Unlike in some dormitory towns, the residents appear to have made commitments to their place of residence as they generally expect to be there in the long term. They carry out much of their leisure activities in the towns and wish to develop these possibilities further, rather than continue to travel outside for these. The increasing property prices in the Greater Dublin area and continuing improvements in transport infrastructure, such as road building further west, are likely to lead to similar developments taking place increasingly further from Dublin. Further studies of towns more distant from the Capital would be likely to provide examples of change similar to that reported here just beginning to take place.

This paper raises a number of more general possibilities for further geographical study. It would be informative to contrast the development of settlement in north Kildare with a similar area on the fringe of a major conurbation where there was a unitary planning system for the whole region. The relationship between the growth of the north Kildare towns and the improvements in transport infrastructure provide pointers towards further change within the Dublin region. The social behaviour of the inhabitants of the area and the changing provision of services to meet their needs, illustrate possible more general changes in life in Irish towns. An aspect of immediate note is the changing central place role of Kilcock. This provides an interesting pointer to the effects of the expansion of the influence of larger settlements on the centrality of smaller towns which were formerly relatively outside their influence. Both in terms of town planning and of landscape change, the towns of North Kildare provide a case study, which is of use for monitoring future local development and to facilitate comparisons with other areas of greater Dublin.

\section{Acknowledgements}

Thanks are due to Brendan Bartley for his helpful comments on previous drafts of this paper, to the students who participated in the questionnaire surveys, the Celbridge Community Council, the Kilcock and Districts Community Council and to the communities of Maynooth, Celbridge and Kilcock who so willingly answered the questions. The author 
gratefully acknowledges the support of KELT, the Department of Agriculture and Food and the European Union, under the Leader 2 programme, in the production of the Kilcock and Districts Survey.

\section{References}

AALEN, F.H.A., COLHOUN, E.A., GILLMOR, D.A. and HORNER, A.A. (1970) County Kildare: A geographical background for planning. Two volumes. Dublin: Trinity College.

AALEN, F.H.A. (1972) Planning in the Metropolitan Hinterland, Co. Kildare, Administration, 20, 5-28.

ABERCROMBIE, P., KELLY, S. and ROBERTSON, M. (1941) Sketch development plan for Dublin. Dublin: Dublin Corporation.

DUBLIN COMMISSION (1926) Report of the Greater Dublin Commission of Inquiry. Dublin: Stationery Office.

CONNELL, J. (1974) The Metropolitan Village: Spatial and Social Processes in Discontinuous Villages, In: Johnson, J.H. (ed.) Suburban Growth: Geographical Processes at the Edge of the Western City. Chichester: Wiley, 77-100.

DAVIES, W.K.D. and HERBERT, D.T. (1993) Communities Within Cities. London: Belhaven Press.

DUFFY, P.J. (1987) The Dublin Region: A Perspective on the Fringe, In: Horner, A.A. and Parker, A.J. (eds) Geographical Perspectives on the Dublin Region. Special Publication No. 2. Dublin: Geographical Society of Ireland, 113-125.

EASTERN REGIONAL DEVELOPMENT ORGANISATION (1985) Eastern Region Settlement Strategy 2011. Dublin: ERDO.

EASTERN REGIONAL DEVELOPMENT ORGANISATION (1988) Eastern Region Settlement Strategy 2001. Dublin: ERDO.

FISCHER, C. (1981) The public and private worlds of city life, American Sociological Review, 46, 306316.

FRANKENBERG, R. (1966) Communities in Britain: Social life in town and country. Harmonsworth: Penguin.

GILLMOR, D.A. (1988) An investigation of villages in the Republic of Ireland, Irish Geography, 21 (2), 57-68.

HORNER, A.A. (1988) Developments in early morning public transport as an indicator of change in the Dublin City region, Irish Geography, 21(1), 45-47.

HORNER, A. A. (1992) Dublin from the 1930s to the 1990s, In: Aalen, F.H.A. and K. Whelan, K. (eds) Dublin City and County: from prehistory to present. Dublin: Geography Publications, 327-358.

JOHNSON, J.H. (1956) The geography of a Belfast suburb, Irish Geography, 3(3), 150-161.

KILDARE COUNTY COUNCIL (1999) Kildare County Development Plan. Naas: Kildare County Council.

KILDARE COUNTY COUNCIL (1996) Amended Draft Kildare County Development Plan. Naas: Kildare County Council.

WADDINGTON, S.B. (1996) The Maynooth Report, Maynooth: St Patrick's College.

WADDINGTON, S.B. (1998) The Celbridge Report:a community study. Maynooth: National University of Ireland, Maynooth.

WADDINGTON, S.B. (1999) The Kilcock and Districts Community Survey. Maynooth: National University of Ireland, Maynooth.

WELLMAN, B. and BERKOVITZ, S. (1988) Social Structure. Cambridge: Cambridge University Press.

WIRTH, L. (1938) Urbanism as a way of life, American Journal of Sociology, 44, 8-20.

WRIGHT, M. (1967) The Dublin Region: advisory regional plan and final report. Two parts. Dublin: Stationery Office. 